\title{
Setting Agenda for Medical Education Research in Pakistan
}

\author{
Sarah Ali ${ }^{1}$, Ahsan Sethi ${ }^{2}$
}

\begin{abstract}
Objective: To justify the allocation of human and financial resources, this study aims to identify multiple stakeholders' views of medical education research priorities in Pakistan for the next five years.

Methods: This two-stage exploratory mixed-method study was conducted from Jan 2018 to Jun 2019. A purposively selected sample of 250 faculty members, research supervisors, postgraduate students, undergraduate students and policymakers actively involved in improving Medical Education were included. In Stage-I: An exploratory open-ended questionnaire asking about Medical Education Research (MER) priorities in Pakistan for the next five years was emailed. Data were thematically analyzed to identify MER areas. In Stage-II: Another questionnaire was developed based on MER areas. The participants were asked to rate their importance on a scale of one to five. Descriptive statistics were calculated using SPSS.v.24.

Results: In Stage-I, 140 participants and in Stage-II, 130 participants from different stakeholder groups responded. We identified 20 research priorities grouped under eight themes: curriculum organization, content, delivery, assessment, workplace, students, faculty and educational management. Top three research priorities were identifying needs and developing effective provisions for continuous professional development of the faculty, improving assessment and communication skills.

Conclusion: The study identified top MER priority areas as continuous professional development, assessment and communication skills. Some areas unique to the current study include admissions, fostering critical thinking, Islamic values in professionalism and ethics. The study provides evidence-base for decisionmaking about allocating time and funds for MER in Pakistan.
\end{abstract}

KEYWORDS: Health Professions, Medical Education, Priority, Research.

doi: https://doi.org/10.12669/pjms.37.3.3603

How to cite this:

Ali S, Sethi A. Setting Agenda for Medical Education Research in Pakistan. Pak J Med Sci. 2021;37(3):684-688. doi: https://doi.org/10.12669/pjms.37.3.3603

This is an Open Access article distributed under the terms of the Creative Commons Attribution License (http://creativecommons.org/licenses/by/3.0), which permits unrestricted use, distribution, and reproduction in any medium, provided the original work is properly cited.

1. Sarah Ali

Assistant Registrar,

Pakistan Medical and Dental Council,

Islamabad, Pakistan.

2. Ahsan Sethi

Assistant Professor,

Institute of Health Professions Education and Research, Khyber Medical University, Peshawar, Pakistan.

Note: Both Dr. Sarah Ali and Dr. Ahsan Sethi contributed equally and are co-first authors.

Correspondence:

Dr. Ahsan Sethi

Assistant Professor

Institute of Health Professions Education and Research, Khyber Medical University, Peshawar, Pakistan.

Email: ahsansethi@gmail.com

* Received for Publication:

September 4, 2020

* Revision Received:

* Revision Accepted:

\section{INTRODUCTION}

Medical education has emerged notably as a specialty in many countries abroad, but in Pakistan it has been recognized relatively recently. The interest in medical education can be evaluated by the increasing number of postgraduate programmes in this field worldwide (7 to $126+$ ) and Pakistan (2 to 8), over the last two decades. ${ }^{1}$ Such programmes improve knowledge and encourage transformational changes in educational practices with development as teacher, learner leader and researcher. ${ }^{1,2}$ These roles of a medical educator have been recognized in the literature. ${ }^{3}$

Medical education research aims at developing an understanding of teaching and learning by studying interactions, interventions and phenomena, 
thus providing evidence-base to medical educators and policymakers. ${ }^{4}$ Therefore, it has a profound impact on the healthcare system. ${ }^{5}$ The Higher Education Commission (HEC) Pakistan has developed policies and programmes to encourage research among faculty members in the country. ${ }^{6}$ Likewise, the statutory body governing medical education in Pakistan has made the teaching of research mandatory in the undergraduate and postgraduate curriculum. Research in the respective specialty has been formally linked with promotions of the faculty.

In 2010, the HEC created Offices of Research Innovation \& Commercialization (ORIC) in every Higher Education Institution for 'transforming Pakistani universities to drive high impact innovation, applied research and entrepreneurship'. Therefore, the medical universities must ensure that their research effectively contribute towards improvement in the health and wellbeing of their community. The World Health Organization also emphasized on social accountability in medical institutions: 'the obligation to direct their education, research and service activities towards addressing the priority health concerns of the community, region, and/or nation they have a mandate to serve'. ${ }^{8}$

Few countries (New Zealand, ${ }^{9}$ Canada, ${ }^{10}$ Scotland, ${ }^{11} \operatorname{Iran}^{12}$ and Eastern Mediterranean Region ${ }^{13}$ ) have previously conducted priority-setting exercises for Medical Education Research (MER). Such studies help ensure that MER contributes most effectively towards improvement in existing undergraduate, postgraduate and continuing medical education system. These may also increase ownership of the priorities as interests of relevant people are considered and thus facilitate educational reforms. ${ }^{14}$ Pakistan, is a developing country with limited number of trained medical educationist and research funds, ${ }^{15}$ which mandates evidenceinformed decision making. Our healthcare system, values, culture and hence the MER priorities may differ substantially from those identified in other countries. Hence, the current study aims to identify multiple stakeholders' views of Medical Education Research (MER) priorities in Pakistan for the next five years. The study is timely and will help ensure utilization of resources wisely to maximize research productivity in medical education and healthcare.

\section{METHODS}

This two-stage exploratory mixed-method study was conducted from Jan 2018 to Jun 2019. Ethical approval was granted by Ethics Review Committee, Islamic International Medical Col- lege, Rawalpindi (RIPHAH/IIMC/ERC/17/0241 Dated:04-07-2017).

Questionnaire: In Stage-I: An exploratory openended qualitative questionnaire was developed asking the participants about three Medical Education Research (MER) priorities in Pakistan for the next five years. In Stage-II: Another questionnaire was developed based on MER areas (subthemes/themes) identified in Stage-I asking the participants to rate the importance of these areas on a Likert scale of one (not important) to five (very important) and add new priority areas if they perceived them as absent. The questionnaires were checked for understanding and accessibility.

Data Collection: Participants included purposively selected faculty members, research supervisors, postgraduate students, undergraduate students (International Federation of Medical Students' Associations), Standing Committee on Medical Education) and policy makers (statutory body members), which are actively involved in improving 'Medical Education' in Pakistan. An information sheet and questionnaire were shared through email with 250 participants across the country. Two reminders were sent to encourage participation.

Data Analysis: For qualitative data, the researchers independently read each response and developed a thematic framework of in-vivo codes. The codes were then categorized into subthemes and themes. ${ }^{16}$ Through constant comparison method the subthemes/themes were continuously refined. Quantitative data were analysed using SPSS.v.24. Frequencies and percentages were calculated for demographics. Likert scale ratings of importance for each of the 20 subthemes were computed as medians and interquartile ranges (IQRs). The ratings given to each subtheme by all the participants were summated to identify the total rank scores and the overall rankings.

\section{RESULTS}

In Stage-I, 140 participants and in StageII, 130 participants from diverse stakeholder groups responded. Most of the respondents had postgraduate qualifications in medical education. Majority were from Punjab and Khyber Pakhtunkhwa province. (Table-I).

We identified 20 research priorities grouped under eight themes: curriculum organisation, content, delivery, assessment, workplace, students, faculty and educational management. Top research priorities were identifying needs and developing effective provisions for continuous professional 
Table-I: Participant Characteristics from Stage-I and Stage-II.

\begin{tabular}{|c|c|c|c|c|c|c|c|}
\hline \multicolumn{2}{|c|}{ Characteristics } & \multicolumn{2}{|c|}{$\begin{array}{l}\text { Undergraduate } \\
\text { Medical Students }\end{array}$} & \multicolumn{2}{|c|}{$\begin{array}{l}\text { MHPE Graduates } \\
\text { (Faculty members) }\end{array}$} & \multicolumn{2}{|c|}{$\begin{array}{c}\text { Medical Education } \\
\text { Supervisors/Policymakers }\end{array}$} \\
\hline & & $\begin{array}{l}\text { Stage-I } \\
n(\%)\end{array}$ & $\begin{array}{l}\text { Stage-II } \\
n(\%)\end{array}$ & $\begin{array}{l}\text { Stage-I } \\
n(\%)\end{array}$ & $\begin{array}{l}\text { Stage-II } \\
n(\%)\end{array}$ & $\begin{array}{l}\text { Stage-I } \\
n(\%)\end{array}$ & $\begin{array}{l}\text { Stage-II } \\
n(\%)\end{array}$ \\
\hline \multicolumn{2}{|c|}{ Mean Age (Years) } & $21.45 \pm 1.36$ & $38.20 \pm 9.86$ & $41.33 \pm 8.73$ & $42.59 \pm 9.07$ & $48.29 \pm 9.84$ & $40.95 \pm 10.46$ \\
\hline \multirow[t]{2}{*}{ Gender } & Male & $6(30.0)$ & $11(55.0)$ & $43(54.4)$ & $44(60.3)$ & $25(61.0)$ & $18(48.6)$ \\
\hline & Female & $14(70.0)$ & $9(45.0)$ & $36(45.6)$ & $29(39.7)$ & $16(39.0)$ & $19(51.4)$ \\
\hline \multirow[t]{5}{*}{ Area } & Islamabad & $2(10.0)$ & $2(10.0)$ & 14 (17.7) & 13 (17.8) & $10(24.4)$ & 7 (18.9) \\
\hline & Punjab & $10(50.0)$ & $10(50.0)$ & $40(50.6)$ & $25(34.2)$ & $12(29.3)$ & $20(54.1)$ \\
\hline & Sindh & $2(10.0)$ & $3(15.0)$ & $4(5.1)$ & 10 (13.7) & $13(31.7)$ & $4(10.8)$ \\
\hline & KPK & $1(5.0)$ & $3(15.0)$ & $20(25.3)$ & $23(31.5)$ & $5(12.2)$ & $5(13.5)$ \\
\hline & Baluchistan & $5(25.0)$ & $2(10.0)$ & $1(1.3)$ & $2(2.7)$ & $1(2.4)$ & $1(2.7)$ \\
\hline
\end{tabular}

development of the faculty, designing valid and reliable assessments and also ensuring their quality and standardization, enhancing health professionals' communication amongst each other and the patients or their relatives (Table-II).

\section{DISCUSSION}

This is the first study on setting agenda of medical education research (MER) in Pakistan for next five years. We identified eight themes of medical education research as priorities: curriculum organisation, content, delivery, assessment, workplace, students, faculty and educational management. There is a need to organize the research work around these priorities identified. The resources may be diverted towards researching these areas instead of reliance on research patterns defined by individual academicians based on interests. The outcomes of such prioritization exercises are usually relevant to the context in which it is carried out. In terms of MER areas there are more similarities than differences among our findings and those in other countries..$^{9-13}$ Therefore, we believe that these results may be relevant across the international arena. We recommend similar priority-setting exercises to researchers from other specialties (dental and nursing etc) and in other countries in order to set their MER agendas. All these efforts may contribute towards developing an international MER agenda.

There are differences in terms of the rankings of MER areas identified in the current study and those in other studies. In this study, the top research priority areas were related to effective provisions for continuous professional development, assessments and enhancing communication amongst each other and the patients or their relatives. In Scotland, ${ }^{11}$ the highly ranked area was balancing intersecting clinical and educational identities, ${ }^{17}$ while faculty devel- opment was ranked \#18, which received the highest ranking in our study. Likewise, assessment and communication skills were ranked much lower. These findings are in line with our educational landscape, which is currently evolving with a move towards curriculum integration and more student-centered learning strategies, which demands designing effective means for training of the faculty. There is also a difference in the interpretation of these medical education areas. For example, in Pakistan and $\operatorname{Iran}^{12}$ research is needed over the integration of basic and clinical sciences at undergraduate level, whereas, in Scotland, ${ }^{11}$ it refers to the integration of undergraduate and postgraduate education. It is pertinent to mention here that like any other research priorities, those in medical education might change over the time and therefore would need continuous assessment. For example, the recent COVID-19 pandemic has resulted in diversion of resources and research in facilitating online teaching/learning through various medical education adaptions worldwide. ${ }^{18}$ Probably, if this study is repeated today, the use of technology and innovation in medical education (rank\#14 in Pakistan) would have ranked much higher as a priority worldwide.

Some areas unique to the current study include admission and promotion of medical students, advancing inclusion and diversity in medical education, role modelling, fostering critical thinking, Islamic values in professionalism and ethics. A recent study on predictive ability of the medical students' admissions criteria suggested a weak correlation with grades in the professional examinations. ${ }^{19}$ They suggested assessment of non-cognitive attributes in the admission process. Similarly, other studies ${ }^{20,21}$ also suggested teaching Islamic perspective of medical professionalism that consists of 'faith (Iman), consciousness (Taqwat), best 
Table-II: Medical Education Research (MER) priorities in Pakistan.

\begin{tabular}{|c|c|c|c|c|}
\hline Theme & Subtheme & Definition & $\begin{array}{l}\text { Median } \\
(I Q R)\end{array}$ & $\begin{array}{l}\text { Total Rank Score } \\
\text { (overall ranking) }\end{array}$ \\
\hline $\begin{array}{l}\text { Curriculum } \\
\text { organization }\end{array}$ & $\begin{array}{l}\text { Integration of basic } \\
\text { and clinical sciences }\end{array}$ & $\begin{array}{l}\text { This refers to improving understanding of the horizontal } \\
\text { and vertical integration of disciplines around body sys- } \\
\text { tems, organs or themes in the curriculum. }\end{array}$ & $4(4-5)$ & $575(12)$ \\
\hline \multirow{4}{*}{$\begin{array}{l}\text { Curriculum } \\
\text { content }\end{array}$} & $\begin{array}{l}\text { Community } \\
\text { orientated medical } \\
\text { education }\end{array}$ & $\begin{array}{l}\text { This refers to the inclusion and prioritization of curricu- } \\
\text { lum content based on the evolving needs of the commu- } \\
\text { nity. }\end{array}$ & $5(4-5)$ & $587(6)$ \\
\hline & $\begin{array}{l}\text { Defining core cur- } \\
\text { ricula }\end{array}$ & $\begin{array}{l}\text { This refers to defining standardized minimum core cur- } \\
\text { riculum contents nationwide. }\end{array}$ & $4(4-5)$ & $581(10)$ \\
\hline & $\begin{array}{l}\text { Improving commu- } \\
\text { nication skills }\end{array}$ & $\begin{array}{l}\text { It is important for health professional to learn to commu- } \\
\text { nicate effectively with each other and the patients or their } \\
\text { relatives. }\end{array}$ & $5(4-5)$ & $603(3)$ \\
\hline & $\begin{array}{l}\text { Professionalism } \\
\text { and ethics with } \\
\text { consideration to } \\
\text { Islamic values }\end{array}$ & $\begin{array}{l}\text { This means defining and teaching medical professional- } \\
\text { ism and ethics in line with Islamic values. }\end{array}$ & $5(4-5)$ & $596(4)$ \\
\hline \multirow{3}{*}{$\begin{array}{l}\text { Curriculum } \\
\text { delivery }\end{array}$} & $\begin{array}{l}\text { Use of technology } \\
\text { and innovation in } \\
\text { medical education }\end{array}$ & $\begin{array}{l}\text { It refers to the incorporation of new technology and in- } \\
\text { novations in medical education. }\end{array}$ & $4(4-5)$ & $574(14)$ \\
\hline & $\begin{array}{l}\text { Fostering reflective } \\
\text { and critical thinking }\end{array}$ & $\begin{array}{l}\text { It refers to enhancing metacognitive, reflective and lateral } \\
\text { thinking among students for clinical decision-making and } \\
\text { solving complex problems }\end{array}$ & $4(4-5)$ & $582(9)$ \\
\hline & $\begin{array}{l}\text { Engaging near } \\
\text { peers in teaching }\end{array}$ & $\begin{array}{l}\text { This means encouraging a process of teaching and learn- } \\
\text { ing amongst peers i.e. Peer Assisted Learning }\end{array}$ & $4(4-5)$ & $514(20)$ \\
\hline \multirow{2}{*}{$\begin{array}{l}\text { Assessment } \\
\text { and feedback }\end{array}$} & $\begin{array}{l}\text { Improving assess- } \\
\text { ment practices }\end{array}$ & $\begin{array}{l}\text { This refers to designing valid and reliable assessments } \\
\text { and also ensuring their quality and standardization. }\end{array}$ & $5(4-5)$ & $607(2)$ \\
\hline & $\begin{array}{l}\text { Delivering effective } \\
\text { feedback }\end{array}$ & $\begin{array}{l}\text { It means to understand effective ways of giving and } \\
\text { receiving feedback. }\end{array}$ & $4(4-5)$ & $582(8)$ \\
\hline \multirow{4}{*}{ Workplace } & $\begin{array}{l}\text { Development of } \\
\text { leadership }\end{array}$ & $\begin{array}{l}\text { To understand the development of leadership skills in } \\
\text { healthcare context. }\end{array}$ & $4(4-5)$ & $577(11)$ \\
\hline & $\begin{array}{l}\text { Teamwork and } \\
\text { interprofessional } \\
\text { learning }\end{array}$ & $\begin{array}{l}\text { This refers to the understanding of learning with from and } \\
\text { about other healthcare professionals for working together } \\
\text { as an effective and efficient healthcare team. }\end{array}$ & $5(4-5)$ & $585(7)$ \\
\hline & $\begin{array}{l}\text { Workplace-based } \\
\text { learning }\end{array}$ & $\begin{array}{l}\text { This encompasses the learning of clinical skills in the } \\
\text { workplace }\end{array}$ & $4(4-5)$ & $566(16)$ \\
\hline & $\begin{array}{l}\text { Understanding role } \\
\text { modelling }\end{array}$ & $\begin{array}{l}\text { This mean understanding the learning of norms, values } \\
\text { and practices through role modelling. }\end{array}$ & $4(4-5)$ & $536(19)$ \\
\hline \multirow[b]{2}{*}{ Students } & $\begin{array}{l}\text { Counselling and } \\
\text { mentoring }\end{array}$ & $\begin{array}{l}\text { It refers to the role of counselling and mentoring in help- } \\
\text { ing learners resolve problems and set career-related goals. }\end{array}$ & $4(4-5)$ & 561 (17) \\
\hline & $\begin{array}{l}\text { Admission and pro- } \\
\text { motion of medical } \\
\text { students }\end{array}$ & $\begin{array}{l}\text { It means development of admission and promotion poli- } \\
\text { cies and processes for students in medical colleges and } \\
\text { universities. }\end{array}$ & $4(4-5)$ & 575 (13) \\
\hline \multirow{2}{*}{ Faculty } & $\begin{array}{l}\text { Continuous Profes- } \\
\text { sional Development }\end{array}$ & $\begin{array}{l}\text { This relates with identifying needs and developing effec- } \\
\text { tive provisions for continuous professional development } \\
\text { of the faculty. }\end{array}$ & $5(5-5)$ & $616(1)$ \\
\hline & $\begin{array}{l}\text { Recruitment, ap- } \\
\text { praisal and promo- } \\
\text { tion criteria }\end{array}$ & $\begin{array}{l}\text { This refers to developing appropriate job description, } \\
\text { recruitment process, workload models and promotion } \\
\text { regulations for the faculty }\end{array}$ & $4(4-5)$ & $573(15)$ \\
\hline \multirow{2}{*}{$\begin{array}{l}\text { Educational } \\
\text { management }\end{array}$} & $\begin{array}{l}\text { Total quality man- } \\
\text { agement }\end{array}$ & $\begin{array}{l}\text { It encompasses quality assurance, quality control and } \\
\text { accreditation }\end{array}$ & $5(4-5)$ & $595(5)$ \\
\hline & $\begin{array}{l}\text { Advancing inclu- } \\
\text { sion and diversity }\end{array}$ & $\begin{array}{l}\text { It refers to policies and practices that support diversity } \\
\text { and inclusion initiatives in medical education. }\end{array}$ & $4(4-5)$ & $538(18)$ \\
\hline
\end{tabular}


character (Ahsan al Akhlaq), excellent performance (Itqaan al'Amal), strife toward perfection (Ihsan), responsibility (Amanat), and self-accountability (Muhasabat Alnafs)'. These unique areas reflect areas that need attention in our context. The MER should help develop indigenous and contextually relevant guidelines, norms and standards, rather than passively following those guidelines that do not represent the Pakistani cultural context. ${ }^{22}$ The regulatory bodies of medical education in Pakistan must ensure appropriate funding and protected time for research in medical institutions.

Limitations of the study: In the current study, we selected a purposive sample of faculty members, research supervisors, postgraduate students, undergraduate students and policy makers, who are actively involved in improving 'Medical Education' across institutions and provinces of Pakistan. Moreover, our participants mostly belonged to Punjab, Khyber Pakhtunkhwa and Sindh with fewer participants from Baluchistan province. These participants may or may not be representative of MER stakeholders in the country.

\section{CONCLUSION}

The study identified top medical education research priority areas as continuous professional development, assessment and communication skills. There are more similarities than differences between our findings and those from other countries. Some areas unique to the current study include admission and promotion of medical students, advancing inclusion and diversity in medical education, role modelling, fostering critical thinking, Islamic values in professionalism and ethics. The study provides evidence for researchers, funding bodies, health institutions and policymakers to base decisions on allocation of time and funds for MER in Pakistan.

Acknowledgement: We would like to thank Dr. Ashley Dennis for her feedback on the data analysis and themes.

Conflict of Interest: None.

\section{REFERENCES}

1. Sethi A, Schofield S, McAleer S, Ajjawi R. The influence of postgraduate qualifications on educational identity formation of healthcare professionals. Adv Health Sci Educ Theory Pract. 2018:23(3):567-585. doi: 10.1007/s10459-018-9814-5

2. Sethi A, Schofield S, Ajjawi R, McAleer S. How do postgraduate qualifications in medical education impact on health professionals? Med Teach. 2016;38(2):162-167. doi: 10.3109/0142159X.2015.1009025

3. Bligh J, Brice J. Further insights into the roles of the medica educator: the importance of scholarly management. Acad Med. 2009;84(8):1161-1165. doi: 10.1097/ACM.0b013e3181ace633
4. Ringsted C. Research in medical education. Notf Rett Med. 2009;12(2):57-60. doi: 10.1007/s10049-009-1223-0

5. Meo SA, Sattar K, Habib-Ullah C, Alnassar S, Hajiar W, Usman A. Progress and prospects of medical education research in Asian Countries. Pak J Med Sci. 2019;35(6):1475-1481. doi: 10.12669/ pims.35.6.1147

6. Higher Education Commission. Research \& Development 2020 Available from: https://www.hec.gov.pk/english/research/ Pages/default.aspx. Accessed August 202020

7. Higher Education Commission. Office Of Research, Innovation And Commercialization (ORIC) 2020. Available from: https://www. hec.gov.pk/english/services/universities/ORICs/Documents/ ORIC\%20Policy\%20\%28ISC\%29.pdf (Accessed August 20 2020)

8. Boelen C, Heck JE. Defining and measuring the social accountability of medical schools: World Health Organization; 1995. Available from: https://apps.who.int/iris/bitstream/handle/10665/59441/ WHO HRH 95.7.pdf (Accessed August 18 2020)

9. Wilkinson TJ, Weller JM, McKimm J, O'Connor BJ, Pinnock RE, Poole PJ, et al. Programmatic research in medical education: a national collaboration. N Z Med J. 2010;123(1318):24-33.

10. Hodges BD, Albert M, Arweiler D, Akseer S, Bandiera G, Byrne N, et al. The future of medical education: a Canadian environmental scan. Med Educ. 2011:45(1):95-106. doi: 10.1111/j.1365-2923.2010.03737.x

11. Dennis AA, Cleland JA, Johnston P, Ker JS, Lough M, Rees CE. Exploring stakeholders' views of medical education research priorities: a national survey. Med Educ. 2014;48(11):1078-1091. doi: 10.1111/medu.12522

12. Nabeiei P, Amini M, Ghanavati S, Marhamati S. Research priorities in medical education at Shiraz University of Medical Sciences: categories and subcategories in the Iranian context. J Adv Med Educ Prof. 2016;4(1):26-32.

13. Amini M, Kojuri J, Lotfi F, Karimian Z, Abadi A. Research priorities in medical education in the Eastern Mediterranean Region. East Mediterr Health J. 2012;18(7):687-692.

14. Vella K, Goldfrad C, Rowan K, Bion J, Black N. Use of consensus development to establish national research priorities in critical care. Br Med J. 2000;320(7240):976-980. doi: 10.1136/bmj.320.7240.976

15. Ghaffar A, Zaidi S, Qureshi H, Hafeez A. Medical education and research in Pakistan. Lancet. 2013;381(9885):2234-2236. doi: 10.1016/ S0140-6736(13)60146-4

16. Creswell JW, Creswell JD. Research design: Qualitative, quantitative, and mixed methods approaches: Sage publications; 2017.

17. Sethi A, Ajjawi R, McAleer S, Schofield S. Exploring the tensions of being and becoming a medical educator. BMC Med Educ. 2017;17(1):62. doi: 10.1186/s12909-017-0894-3

18. Eva KW, Anderson MB. Medical Education Adaptations: Really Good Stuff for educational transition during a pandemic. Med Educ. 2020;54(6):494. doi: 10.1111/medu.14172

19. Qazi MA Anwar J, Moffat M. Predictive ability and stakeholders' perceptions of the selection tools for mbbs in women medical college: A mixed methods study. J Ayub Med Coll Abbottabad. 2020;32(1):78-82.

20. Rani MDM, Jamaludin J, Azmi AN, Ramli S, Subri MI, Osman A, et al. Perception of Medical Professionalism among Clinical Students at Universiti Sains Islam Malaysia. J Med. 2017;18(2):56-61. doi: 10.3329/jom.v18i2.33678

21. Kasule $\mathrm{OH}$. Medical professionalism and professional organizations. J Taibah Univ Med Sci. 2013;8(3):137-141. doi: 10.1016/j. jtumed.2013.09.003

22. Kiran NI, Waheed K. Medical Professionalism in Pakistan: Taking Inspiration from the Pakistani Motto. Ann King Edw Med Univ. 2018;24(2):723-724.

\section{Authors' Contribution:}

SA \& AS: Conceived the idea and designed the study.

SA: Was involved in data collection.

Both the authors performed data analysis and contributed towards writing the manuscript and approving the final version, are responsible for integrity of the study. 